\title{
Academic achievement in first-year Portuguese college students: The role of academic preparation and learning strategies
}

\author{
Ana Paula Soares \\ University of Minho, Braga, Portugal
}

Leandro S. Almeida

University of Minho, Braga, Portugal

\author{
M. Adelina Guisande \\ University of Santiago de Compostela, Spain
}

\section{Fernanda Páramo}

University of Santiago de Compostela, Spain

\begin{abstract}
$T$ his paper analyses the role of academic preparation and learning strategies in the prediction of first-year 1 Portuguese college students' academic achievement, considering students' sex and academic field attended. A sample of 445 first-year college students $(68.5 \%$ female) from the University of Minho $(25.8 \%$ enrolled in economics, $35.3 \%$ in science/technology, and $38.9 \%$ in humanities degrees) participated in the study. Students answered a questionnaire on learning strategies in the classroom at the end of the first semester, which consisted of 44 items organized in five dimensions: comprehensive approach, surface approach, personal competency perceptions, intrinsic motivation, and organization of study activities. Academic achievement (grade point average at the end of first year) and academic preparation (students' higher education access mark) were obtained through the academic records of the university. Results showed that academic preparation was the strongest predictor of first-year academic achievement, and only marginal additional variance was explained by learning strategies as assessed by the self-reported questionnaire. There were sex and academic field differences, but these variables do not seem strong enough to affect the results, although the different percentages of variance captured by each model and the different weights associated to higher education access mark, stimulate the use of these and/or other personal and contextual variables when analysing the phenomenon.
\end{abstract}

\footnotetext{
$C$ et article analyse le rôle de la préparation académique et des stratégies d'apprentissage dans la prédiction des résultats académiques des étudiants collégiens portugais de première année, considérant le sexe des étudiants et le champ d'études poursuivies. Un échantillon de 445 étudiants collégiens de première année $(68,5 \%$ féminin) de l'Université de Minho (25,8\% inscrits en économie, 35,3\% en sciences et technologies et 38,9\% en sciences humaines) a participé à cette étude. Les étudiants ont répondu à un questionnaire sur les stratégies d'apprentissage, dans la classe à la fin du premier semestre, lequel consistait à 44 items organisés en cinq dimensions : approche compréhensive, approche de surface, perceptions des compétences personnelles, motivation intrinsèque et organisation des activités d'étude. Les résultats académiques (moyenne des notes à la fin de la première année) et la préparation académique (score combinant les résultats académiques à l'école secondaire et les résultats aux examens d'entrée à l'université) furent obtenus en consultant les dossiers académiques conservés à l'université. Les résultats ont montré que la préparation académique était le plus fort prédicteur des résultats académiques lors de la première année. Seulement une variance marginale additionnelle était expliquée par les stratégies d'apprentissage tel qu'évaluées par le questionnaire auto-rapporté. En dépit des différences relatives au sexe des étudiants et au champ d'études, ces variables ne semblent pas assez puissantes pour affecter les résultats. Malgré tout, les différents pourcentages de variance expliquée par chaque modèle et les différents poids associés à la préparation académique stimulent l'utilisation de ces variables ou d'autres variables personnelles et contextuelles lors de l'analyse du phénomène.
}

Correspondence should be addressed to Ana Paula Soares, Department of Psychology, University of Minho, Campus Gualtar, 4710, Braga, Portugal (E-mail: asoares@iep.uminho.pt).

M. Adelina Guisande was supported by the Ministerio de Educación y Ciencia (Spain). 


\begin{abstract}
$E$ 1 presente trabajo analiza el papel de la preparación académica y las estrategias de aprendizaje en la predicción del rendimiento de los estudiantes del primer curso de la universidad, teniendo en cuenta el sexo de los estudiantes y el campo académico al que pertenecen. La muestra consistió en 445 estudiantes del primer curso (68,5\% mujeres) de la Universidad de Minho (25,8\% matriculados en economía, 35,3\% en ciencia/tecnología, y $38,9 \%$ en humanidades). Los estudiantes contestaron a un cuestionario sobre las estrategias de aprendizaje al final del primer cuatrimestre, el cual consistió en 44 ítems organizados en cinco dimensiones: enfoque comprensivo, enfoque superficial, percepción de la competencia personal, motivación intrínseca y organización de las actividades de estudio. El rendimiento académico (la media de las notas al final del primer curso) y la preparación académica (la nota de acceso a los estudios superiores) fueron obtenidos de los registros de la universidad. Los resultados demostraron que la preparación académica fue el predictor más importante del rendimiento académico en el primer curso y solo la varianza marginal adicional fue explicada por las estrategias de aprendizaje recogidas en el cuestionario de auto-informe. A pesar de las diferencias de género y campo académico, estas variables no parecen suficientemente fuertes como para afectar a los resultados. Aún así, los diferentes porcentajes de varianza capturados por cada modelo y los diferentes pesos asociados a las notas de acceso a los estudios estimulan el uso de estas y/u otras variables personales y contextuales al analizar este fenómeno.
\end{abstract}

Keywords: Academic achievement; Academic preparation; First-year college students; Higher education; Learning strategies.

Academic achievement and retention are prevalent themes in higher education literature. Research shows that both secondary school grades and scores on standardized tests such as the SAT (Scholastic Aptitude Tests) or the ACT (American College Testing) are important predictors of student academic achievement in higher education (e.g., Hoffman \& Lowitzki, 2005; Kamera, Reuben, \& Sillah, 2003; Mouw \& Khanna, 1993; Robbins et al., 2004). In general, studies show that secondary school grades account for approximately $20 \%$ of the variance in college achievement, while standardized test scores account for approximately $18 \%$. When we combine SAT or ACT scores with secondary school classifications, that is, when we control the covariance in both measures, nearly $25 \%$ of variance can be explained (ACT, 1997; Mouw \& Khanna, 1993). Similar rates of explained variance have been found in Portugal (Soares, Guisande, Diniz, \& Almeida, 2006), where there is a numerus clausus system in the access to university based on students' higher education access mark, a score that combines secondary school grades $(50 \%)$ and the results obtained in specific access exams, i.e., those directly related to the academic field in which students wish to study $(50 \%)$.

Despite the importance of these predictors, a large percentage of variance is not explained. For example, Mouw and Khanna (1993) mention that $30 \%$ of the students who were expected to succeed in higher education end up failing, whereas $50 \%$ of those who were expected to fail, do in fact succeed. To explain these discrepancies, recent research has considered student behaviour and learning to be important factors in student's academic success and retention.

Study skills and learning approaches include, for example, time management, using information resources, taking class notes, communicating with teachers, preparing for and taking examinations, and several other learning strategies. The research shows a significant correlation between such learning behaviour and approaches and academic achievement in higher education (e.g., Bol, Warkentin, Nunnery, \& O'Connell, 1999; Capella, Wagner, \& Kusmierz, 1982; Gadzella, Ginther, \& Williamson, 1987; Kern, Fagley, \& Miller, 1998; Robbins et al., 2004; Schultz \& Lanehart, 1994). Capella et al., for example, obtained a correlation of .46 between a measure of study habits and attitudes and higher education academic achievement. Other studies found lower academic achievement in students who showed deficits in study skills (Al-Hilawani \& Sartawi, 1997; Jones, Slate, \& Kyle, 1992), as well as the possibility of increasing academic achievement after training students in these learning competencies (Nelson et al., 1993; Polansky, Horan, \& Hanish, 1993). In a meta-analysis, Hattie, Biggs, and Purdie (1996) conclude that if we aim to increase student academic success in higher education institutions we must focus on interventions directed towards learning strategies, a fact which suggests the need to develop programs of this kind.

However, the impact of a student's academic background and learning approaches on academic achievement is not linear. Some authors highlight the necessity of controlling variables such as 
sex or academic field attended if we want to obtain an improved picture of their impact on a college student's academic achievement (Braxton \& Hargens, 1996; Cano, 2000; Soares, Almeida, Diniz, \& Guisande, 2006). As several different studies have demonstrated, study strategies seem to be a better predictor of academic achievement for female than for male college students (e.g., AlHilawani \& Sartawi, 1997; Grimes, 1995; Zheng, Kevin, Saunders, \& Shelley, 2002), a fact that may justify their higher academic achievement despite lower scores in university access examinations (cf. Leonard \& Jiang, 1999; Young \& Fisler, 2000).

Other studies have also shown that male and female students differ in the type of study competencies presented and that this relationship seems to be mediated by the type of subject being considered or area of studies attended. Regardless of the inconsistency of results in literature (due, in part, to methodological problems - cf. Severiens \& Ten Dam, 1994), in the studies where some differences are observed, male students present a deeper learning approach and extrinsic motivation, and female students present more intrinsic motivation and a surface approach to learning (AlHilawani \& Sartawi, 1997; Cano, 2000; Meyer, 1995; Severiens \& Ten Dam, 1994).

At the same time, the academic domains must be considered. In fact, different disciplines or areas seem not only to attract different types of students (due, for example, to their interests, values, and abilities), but to stimulate different types of study competencies (Bol et al., 1999; Hativa \& Birenbaum, 2000; Trigwell \& Prosser, 1991). For example, Zhang (2000) found that a memoristic approach can be positively related to the achievement in chemistry and geography disciplines, but negatively related to language disciplines. Logically, these results may also be influenced by the teaching methodologies and evaluation methods used in each curricular field (Brown, Bull, \& Pendlebury, 1997; Hativa \& Birenbaum, 2000).

Furthermore, the literature recognizes that, in spite of secondary school grades and/or scores on standardized tests to access higher education being important predictors of college academic achievement on the one hand, and correlations between it and study competencies being positive and stastically significant on the other, the relationship between learning strategies and academic preparation on academic achievement lacks clarification (e.g., Pintrich \& DeGroot, 1990; Pokay \& Blumenfeld, 1990; Robbins et al., 2004). In this context, and assuming these concerns, this paper intends: (1) to assess sex and academic field differences in students' perceptions of study skills and learning approaches, as well as in levels of academic preparation and academic achievement; and (2) to determine the role played by study skills and learning approaches and academic preparation in the prediction of first-year college students' academic achievement, considering their sex and academic field attended.

To fulfil these purposes, we first analysed students' perceptions of study skills and learning strategies (as assessed by the Attitudes and Study Behaviors Inventory-ASBI), as well as levels of academic preparation (higher education access mark) and academic achievement (grade point average - GPA), by sex and academic field. Then, a hierarchical regression analysis was designed to assess the specific contribution of ASBI dimensions and higher education access mark on the prediction of first-year Portuguese college students' academic achievement. The SPSS statistic package (version 15.0 for Windows) was used.

\section{METHOD}

\section{Participants and procedures}

The sample consisted of 445 first-year college students $(68.5 \%$ female), with ages ranging from 17 to 57 years old $(M=18.3, S D=2.2)$ from the University of Minho (Portugal); 25.8\% were enrolled in economics, $35.3 \%$ in science/technology, and $38.9 \%$ in humanities. There were more female students in humanities $(78.6 \%)$ and in economics (73.9\%), while in sciences/technologies the situation was more balanced (53.5\% of female students).

Students answered the questionnaire in their classroom at the end of the first semester. The response time was about 20 minutes. They were informed about the study purposes and assured about result confidentiality. Participation was voluntary and there was no financial compensation. Students who participated in the study also authorized access to their academic records at university (higher education access mark and GPA).

\section{Instruments}

The Attitudes and Study Behaviors Inventory (ASBI; Tavares, Almeida, Vasconcelos, \& Bessa, 2003) is a self-reported questionnnaire to assess cognitive, behavioural, and motivational factors related to students' study habits and learning approaches in higher education. It includes 44 items organized in five dimensions: (1) comprehensive approach (10 items related to deep learning 
TABLE 1

Means and standard deviations in the learning dimensions by academic field and sex

\begin{tabular}{|c|c|c|c|c|c|c|c|c|c|c|c|}
\hline \multirow[b]{3}{*}{ Group } & \multicolumn{11}{|c|}{ Learning dimensions } \\
\hline & \multirow[b]{2}{*}{$n$} & \multicolumn{2}{|c|}{$\begin{array}{c}\text { Comprehensive } \\
\text { approach }\end{array}$} & \multicolumn{2}{|c|}{ Surface approach } & \multicolumn{2}{|c|}{$\begin{array}{c}\text { Study activities } \\
\text { organization } \\
\end{array}$} & \multicolumn{2}{|c|}{$\begin{array}{c}\text { Intrinsic } \\
\text { motivation }\end{array}$} & \multicolumn{2}{|c|}{$\begin{array}{c}\text { Self-competency } \\
\text { perceptions }\end{array}$} \\
\hline & & $M$ & $S D$ & $M$ & $S D$ & $M$ & $S D$ & $M$ & $S D$ & $M$ & $S D$ \\
\hline \multicolumn{12}{|l|}{ Economics } \\
\hline Male & 30 & 3.73 & 0.59 & 3.64 & 0.77 & 2.83 & 0.82 & 4.26 & 0.74 & 4.13 & 0.78 \\
\hline Female & 85 & 3.82 & 0.72 & 3.89 & 0.73 & 3.29 & 0.72 & 4.48 & 0.71 & 3.99 & 0.74 \\
\hline \multicolumn{12}{|c|}{ Science/Tech. } \\
\hline Male & 73 & 3.60 & 0.68 & 3.64 & 0.78 & 2.78 & 0.76 & 4.32 & 0.73 & 4.05 & 0.61 \\
\hline Female & 84 & 3.61 & 0.64 & 3.95 & 0.75 & 3.14 & 0.67 & 4.36 & 0.67 & 3.82 & 0.74 \\
\hline \multicolumn{12}{|c|}{ Humanities } \\
\hline Male & 37 & 3.82 & 0.81 & 3.86 & 0.88 & 3.08 & 0.90 & 4.19 & 0.82 & 4.38 & 0.70 \\
\hline Female & 136 & 3.79 & 0.70 & 4.02 & 0.74 & 3.12 & 0.76 & 4.50 & 0.73 & 4.25 & 0.74 \\
\hline
\end{tabular}

strategies associated with a significant comprehension of the curriculum contents, $\alpha=.86$ ); (2) surface approach (8 items related to study-learning strategies based on memorization and repetition of the information, $\alpha=.81$ ); (3) study activities organization (10 items reported the students' daily habits regarding the planning of study time, material, and other resources, $\alpha=.83$ ); (4) intrinsic motivation ( 8 items related to an intrinsic motivation and high interest in learning activities inside and out of the classroom, $\alpha=.83$ ); and (5) selfcompetency perceptions ( 8 items concerning personal perceptions about their capacities to succeed in the academic tasks, $\alpha=.80$ ). The items are answered in a 6-point Likert scale (from $1=$ never to $6=$ always). In order to facilitate a comparative data analysis, the score obtained in the five subscales was divided by number of items in each.

Academic preparation was assessed by the higher education access mark, which reflects a combined score of the average of the classifications obtained at the end of secondary school $(50 \%)$ with the classifications obtained in the entrance exam to university $(50 \%)$. The entrance exam is based on curricular knowledge evaluation tests in specific areas (i.e., related with the type of academic field that the students wish to attend in higher education).

Academic achievement was measured by grade point average (GPA) at the end of the first year.

\section{RESULTS}

Table 1 shows students' results in the five dimensions of ASBI (means and standard deviations) considering students' domain of graduation and sex. We used MANOVA to evaluate the effect of those variables on ASBI dimensions. A post hoc Scheffé test was applied.

Results showed an appropriate variability of the values obtained in the five subscales (see Table 1). The MANOVA did not reveal any significant interaction effects, but a significant main effect of students' sex and academic field attended was seen in four of the ASBI dimensions. Female students exhibited higher values on surface approach, $F(1$, $403)=8.864, p<.01$, study activities organization, $F(1,403)=11.190, p<.01$, and intrinsic motivation, $F(1,403)=4.632, p<.05$, while male students showed higher values on self-competency perceptions, $F(1,403)=4.852, p<.05$. Humanities students compared with science/technology (means difference $=0.35, p<.01$ ) and with economics (means difference $=0.26, p<.05$ ) showed more positive self-competency perceptions, $F(2,403)=9.428, p<.01$.

Table 2 presents students' higher education access mark and GPA. Results were depicted by academic domain due to its curricular characteristics.

The results showed some differences in academic field and sex, confirmed by $t$-test analysis. In economics, male students presented higher GPA, $t(113)=2.489, p<.05$, whereas in the science/ technology field, female students presented higher results of academic achievement, $t(155)=-2.371$, $p<.05$, and higher education access marks, $t(155)$ $=-3.473, p<.01$. In the humanities, female students presented higher college access scores, $t(171)=-2.977, p<.01$.

Correlations between academic performance and ASBI dimensions by academic field are depicted in Tables 3 to 5. Each correlation matrix shows the correlations separately for males (bottom half) and females (top half). 
TABLE 2

Means and standard deviations in the higher education access mark and grade point average by academic field and sex

\begin{tabular}{|c|c|c|c|c|c|}
\hline \multirow[b]{2}{*}{ Group } & \multirow[b]{2}{*}{$n$} & \multicolumn{2}{|c|}{ Higher education access mark } & \multicolumn{2}{|c|}{ Grade point average } \\
\hline & & $M$ & $S D$ & $M$ & $S D$ \\
\hline \multicolumn{6}{|l|}{ Economics } \\
\hline Male & 30 & 14.89 & 1.56 & 12.87 & 1.51 \\
\hline Female & 85 & 15.00 & 1.14 & 12.16 & 1.27 \\
\hline \multicolumn{6}{|c|}{ Science/Tech. } \\
\hline Male & 73 & 14.14 & 1.69 & 12.10 & 1.14 \\
\hline Female & 84 & 15.00 & 1.44 & 12.56 & 1.25 \\
\hline \multicolumn{6}{|l|}{ Humanities } \\
\hline Male & 37 & 14.56 & 1.71 & 13.22 & 1.78 \\
\hline Female & 136 & 15.47 & 1.65 & 13.54 & 1.81 \\
\hline
\end{tabular}

TABLE 3

Correlation coefficients for male (bottom half) and female (top half) in economics

\begin{tabular}{llllllll}
\hline & 1 & 2 & 3 & 4 & 5 & 6 & 7 \\
\hline 1 Grade point & & $.47^{* *}$ & .01 & $.23^{*}$ & $.24^{*}$ & -.02 & $.27^{*}$ \\
$\quad$ average & & & & & & & \\
2 Higher education access mark & $.53^{* *}$ & - & $.23^{*}$ & $.23^{*}$ & $.27^{*}$ & .07 & $.39^{* *}$ \\
3 Comprehensive approach & .33 & $.61^{* *}$ & - & $.71^{* *}$ & $.60^{* *}$ & $.69^{* *}$ & .03 \\
4 Surface approach & .29 & .31 & $.59^{* *}$ & - & $.64^{* *}$ & $.65^{* *}$ & .15 \\
5 Study activities organization & $.36^{*}$ & $.40^{*}$ & $.45^{*}$ & .32 & - & $.43^{* *}$ & .05 \\
6 Intrinsic motivation & -.04 & .29 & $.68^{* *}$ & $.67^{* *}$ & .22 & -.03 & .11 \\
7 Self-competency perceptions & .10 & .32 & .14 & -.04 & .03 & .27 & - \\
\hline
\end{tabular}

$* p<.05, * * p<.01$ (two-tailed).

TABLE 4

Correlation coefficients for male (bottom half) and female (top half) in science/technology

\begin{tabular}{llllllll}
\hline & 1 & 2 & 3 & 4 & 5 & 6 & 7 \\
\hline 1 Grade point average & - & $.49^{* *}$ & -.05 & .04 & .02 & .02 & $.25^{*}$ \\
2 Higher education access mark & $.28^{*}$ & - & .11 & -.09 & .10 & -.07 & .17 \\
3 Comprehensive approach & .09 & .23 & - & $.67^{* *}$ & $.64^{* *}$ & $.58^{* *}$ & -.07 \\
4 Surface approach & .09 & -.07 & $.60^{* *}$ & - & $.55^{* *}$ & $.56^{* *}$ & -.11 \\
5 Study activities organization & .08 & -.07 & $.51^{* *}$ & $.48^{* *}$ & - & $.43^{* *}$ & -.13 \\
6 Intrinsic motivation & .07 & .10 & $.69^{* *}$ & $.51^{* *}$ & $.42^{* *}$ & - & -.13 \\
7 Self-competency perceptions & .10 & .14 & .05 & .04 & -.14 & -.10 & - \\
\hline
\end{tabular}

$* p<.05, * * p<.01$ (two-tailed).

TABLE 5

Correlation coefficients for male (bottom half) and female (top half) in humanities

\begin{tabular}{llllllll}
\hline & 1 & 2 & 3 & 4 & 5 & 6 & 7 \\
\hline 1 Grade point average & - & $.70^{* *}$ & $.34^{* *}$ & $.39^{* *}$ & $.19^{*}$ & $.31^{* *}$ & .11 \\
2 Higher education access mark & $.64^{* *}$ & - & $.43^{* *}$ & $.34^{* *}$ & .07 & $.32^{* *}$ & .13 \\
3 Comprehensive approach & .27 & .23 & - & $.69^{* *}$ & $.53^{* *}$ & $.61^{* *}$ & .15 \\
4 Surface approach & .25 & .10 & $.83^{* *}$ & - & $.54^{* *}$ & $.59^{* *}$ & .07 \\
5 Study activities organization & .17 & -.09 & $.62^{* *}$ & $.77^{* *}$ & - & $.39^{* *}$ & .00 \\
6 Intrinsic motivation & .11 & .18 & $.83^{* *}$ & $.79^{* *}$ & $.59^{* *}$ & - & .02 \\
7 Self-competency perceptions & .27 & $.34^{*}$ & -.03 & -.09 & -.10 & -.16 & - \\
\hline
\end{tabular}

$* p<.05, * * p<.01$ (two-tailed). 
Higher correlations were observed between the two measures of academic performance (higher education access mark and GPA) and the ASBI dimensions (except on self-competency perceptions). It was also possible to observe lower correlations between ASBI and GPA for science/ technology students.

Tables 6 to 8 present the results of the hierarchical regression analysis to predict students' first-year GPA, taking the five dimensions of ASBI as a first

TABLE 6

Summary of hierarchical regression analysis for male and female in economics

\begin{tabular}{|c|c|c|c|}
\hline GPA predictors & $B$ & $S E B$ & $\beta$ \\
\hline \multicolumn{4}{|l|}{ Male } \\
\hline \multicolumn{4}{|l|}{ Model 1: $R^{2}=.13, F=4.283^{*}$} \\
\hline Study activities organization & .67 & .32 & $.36^{*}$ \\
\hline \multicolumn{4}{|c|}{ Model 2: $R^{2}=.31, F=6.106^{* *}, \Delta R^{2}=.18$} \\
\hline Study activities organization & .32 & .32 & .17 \\
\hline Higher education access mark & .05 & .02 & $.46^{*}$ \\
\hline \multicolumn{4}{|l|}{ Female } \\
\hline \multicolumn{4}{|l|}{ Model 1: $R^{2}=.07, F=6.577^{*}$} \\
\hline Self-competency perceptions & .46 & .18 & $.27^{*}$ \\
\hline \multicolumn{4}{|c|}{ Model 2: $R^{2}=.13, F=5.943^{* *}, \Delta R^{2}=.06$} \\
\hline Self-competency perceptions & .44 & .18 & $.26^{*}$ \\
\hline Study activities organization & .41 & .18 & $.23^{*}$ \\
\hline \multicolumn{4}{|c|}{ Model 3: $R^{2}=.25, F=8.901^{* *}, \Delta R^{2}=.12$} \\
\hline Self-competency perceptions & .19 & .18 & .11 \\
\hline Study activities organization & .23 & .18 & .13 \\
\hline Higher education access mark & .04 & .01 & $.39 * *$ \\
\hline
\end{tabular}

$* p<.05, * * p<.01$.

TABLE 7

Summary of hierarchical regression analysis for male and female in science/technology

\begin{tabular}{|c|c|c|c|}
\hline$G P A$ predictors & $B$ & $S E B$ & $\beta$ \\
\hline \multicolumn{4}{|l|}{ Male } \\
\hline \multicolumn{4}{|l|}{ Model 1: $R^{2}=.08, F=5.975^{*}$} \\
\hline Higher education access mark & .02 & .01 & $.28^{*}$ \\
\hline \multicolumn{4}{|l|}{ Female } \\
\hline \multicolumn{4}{|l|}{ Model 1: $R^{2}=.06, F=5.401^{*}$} \\
\hline Self-competency perceptions & .42 & .18 & $.25^{*}$ \\
\hline \multicolumn{4}{|c|}{ Model 2: $R^{2}=.27, F=14.748^{* *}, \Delta R^{2}=.21$} \\
\hline Self-competency perceptions & .29 & .16 & .17 \\
\hline Higher education access mark & .04 & .01 & $.46^{* *}$ \\
\hline
\end{tabular}

$* p<.05, * * p<.01$.

TABLE 8

Summary of hierarchical regression analysis for male and female in humanities

\begin{tabular}{|c|c|c|c|}
\hline$G P A$ predictors & $B$ & $S E B$ & $\beta$ \\
\hline \multicolumn{4}{|l|}{ Male } \\
\hline \multicolumn{4}{|l|}{ Model 1: $R^{2}=.41, F=23.970^{* *}$} \\
\hline Higher education access mark & .07 & .01 & $.64^{* *}$ \\
\hline \multicolumn{4}{|l|}{ Female } \\
\hline \multicolumn{4}{|l|}{ Model 1: $R^{2}=.15^{* *}, F=24.086^{* *}$} \\
\hline Surface approach & .95 & .19 & $.39 * *$ \\
\hline \multicolumn{4}{|c|}{ Model 2: $R^{2}=.51, F=69.651^{* *}, \Delta R^{2}=.36$} \\
\hline Surface approach & .42 & .16 & $.17^{* *}$ \\
\hline Higher education access mark & .07 & .01 & $.64 * *$ \\
\hline
\end{tabular}

$* p<.05, * * p<.01$. 
block of variables in the analysis, and looking for additional variance to be explained by the academic preparation variable (second block). These analyses were done separately for the three academic fields and males and females.

Tables 6 to 8 show that the explanatory capacity of the model was quite variable, with $R^{2}$ values ranging from .08 (male students in science/ technology) to .51 (female students in humanities). The higher education access mark in each model was the strongest predictor of first-year GPA, and only marginal additional variance was explained by learning strategies. In fact, it was the unique variable associated with first-year academic achievement in male students from science/technology and humanities, even though its weight varies considerably in each model $(\beta=.28$ in male students from science/technology to $\beta=.64$ in male students from humanities). Furthermore, it is important to underline that in three of these groups (females and males from economics and females from science/technology), the inclusion of the access mark excludes the variables associated with learning strategies that appear in the first block. Finally, the dimension surface approach only persists in the final model for female students from the humanities.

\section{DISCUSSION}

The results allow us to highlight the relevance of the students' academic preparation (i.e., students' higher education access mark), as opposed to their study skills and learning strategies (as assessed by ASBI), for predicting their first-year academic achievement (i.e., GPA). Like other studies, although based on different access requirements (e.g., Hoffman \& Lowitzki, 2005; Kamera et al., 2003; Mouw \& Khanna, 1993; Robbins et al., 2004), our results point out that the higher education access mark was the strongest predictor of first-year Portuguese students' academic achievement. In effect, and although showing different variance percentages according to sex and academic field attended, the higher education access mark is always the most important variable.

The variables associated with students' study skills and learning strategies seem to have a secondary role. Thus, in the hierarchical regression analysis it was confirmed that in spite of the fact that some variables (study activities organization, self-competency perceptions, and surface approach) assume, as in the literature (e.g., Bol et al., 1999; Capella et al., 1982; Gadzella et al., 1987; Kern et al., 1998; Robbins et al., 2004;
Schultz \& Lanehart, 1994), a certain capacity to predict academic achievement, in a first step of analysis these are excluded when the access mark is introduced (except in the female students from humanities, where the surface approach dimension was maintained as a significant variablealthough its predictive value is substantially inferior to the access mark). This situation could be due to the composition of the access mark on which entrance to higher education in Portugal is based. This mark, in combining the average of the classifications obtained in the secondary school and in the university entrance exams, could justify the fact that it constitutes a more reliable predictor of student success in higher education (i.e., the idea that previous academic performance is the best predictor of subsequent academic performance) than the more procedural variables associated with the way students study.

However, before producing definitive conclusions, further investigation should be developed in order to overcome some of the methodological limitations of this paper; specifically, a nonexperimental design and a self-reported questionnaire were used to assess students' perceptions of study skills and learning strategies. In fact, a selfreported measure like the ASBI has an inherent weakness of being subjective, as it requires that individuals make their own judgment about their preferences, which may lead to biased results. Thus, we should be careful regarding the conclusions we draw and carry out more research that relies on different instrumentation measures. We should also call attention to the differences recorded when sex and academic field attended were considered.

Although the regression models obtained showed more similarities than differences, it is important to highlight the different percentages of variance captured by each model, which seems to point to some group specificities. In the humanities, for example, considerable variance was explained (as much in the male group - 41\%-as, above all, in the female group, where the access mark is associated with a surface approach to the capture of $51 \%$ of variance), although in the economics group of males only $8 \%$ was captured. This situation suggested the existence of important differences, encouraging further research that takes these and/or other academic variables into consideration. Students in higher education do not seem to constitute a homogeneous group, and these differences should be addressed if we wish to obtain a more precise idea of what really matters in higher education academic success. 
The descriptive analyses undertaken also corroborate these differences. For example, female students (namely in science/technology and the humanities) presented better higher education access marks, as well as better scores in organizing and planning time dedicated to study, and in the level of motivation and involvement in academic tasks. Female students also presented a more surface approach to learning, as well as lower academic self-competency perceptions. This data is consistent with that presented in the literature (e.g., Al-Hilawani \& Sartawi, 1997; Cano, 2000; Grimes, 1995; Severiens \& Ten Dam, 1994; Zheng et al., 2002), although the superiority of female students in their academic preparation has not frequently been found in studies using SAT or ACT scores (cf. Leonard \& Jiang, 1999; Young \& Fisler, 2000).

To conclude, results suggest that, in the Portuguese context as in other Saxon countries, the higher education access mark, rather than student study skills and learning strategies, has a determinant role in the explanation of college academic achievement. Nevertheless, and in spite of the value of the obtained results, we should develop more investigations that overcome the study limitations discussed, and that consider other variables in the phenomenon. If students in higher education are differentiated with regard to their abilities, interests, and values, it is important to include those variables in future studies (e.g., Braxton \& Hargens, 1996; Cano, 2000). We should consider the possibility of testing these relations at aother times students' academic experience. In fact, we consider that academic preparation may be more relevant to the explanation of students' academic achievement in the first year than in other academic years, due to the greater exposition to the college environment.

Manuscript received May 2006

Revised manuscript accepted June 2007 First published online January 2008

\section{REFERENCES}

ACT. (1997). ACT assessment technical manual. Iowa City, IA: Author.

Al-Hilawani, Y. A., \& Sartawi, A. A. (1997). Study skills and habits of female university students. College Student Journal, 31, 537-545.

Bol, L., Warkentin, R. W., Nunnery, J. A., \& O'Connell, A. A. (1999). College students' study activities and their relationship to study context, reference course, and achievement. College Student Journal, 33, 608-623.

Braxton, J. M., \& Hargens, L. L. (1996). Variation among academic disciplines: Analytical frameworks and research. In J. S. Smart (Ed.), The handbook of theory and research in higher education (pp.1-46). New York: Agathon Press.

Brown, G., Bull, J., \& Pendlebury, M. (1997). Assessing student learning in higher education. London: Routledge.

Cano, F. (2000). Diferencias de género en estrategias y estilos de aprendizaje. Psicothema, 12, 360-367.

Capella, B. J., Wagner, M., \& Kusmierz, J. A. (1982). Relation of study habits and attitudes to academic performance. Psychological Reports, 50, 593-594.

Gadzella, B. M., Ginther, D. W., \& Williamson, J. D. (1987). Study skills, learning processes and academic achievement. Psychological Reports, 54, 923-929.

Grimes, S. K. (1995). Targeting academic programs to student diversity utilizing learning styles and learning-study strategies. Journal of College Student Development, 36, 422-430.

Hativa, N., \& Birenbaum, M. (2000). Who prefers what? Disciplinary differences in students' preferred approaches to teaching and learning styles. Research in Higher Education, 41, 209-236.

Hattie, J., Biggs, J., \& Purdie, N. (1996). Effects of learning skills interventions on student learning: A meta-analysis. Review of Educational Research, 66, 99-136.

Hoffman, J. L., \& Lowitzki, K. E. (2005). Predicting college success with high school grades and test scores: Limitations for minority students. Review of Higher Education, 28, 455-474.

Jones, C. H., Slate, J. R., \& Kyle, A. (1992). Study skills of teacher education students. Teacher Education, 28, $7-15$.

Kamera, D., Reuben, L. J., \& Sillah, M. R. (2003). The effects of academic environment and background characteristics on student satisfaction and performance: The case of South Carolina State University's School of Business. College Student Journal, 37, 298-308.

Kern, C. W., Fagley, N. S., \& Miller, P. M. (1998). Correlates of college retention and GPA: Learning and study strategies, testwiseness, attitudes, and ACT. Journal of College Counseling, 1, 26-34.

Leonard, D. K., \& Jiang, J. (1999). Gender bias and the college predictions of the SATs: A cry of despair. Research in Higher Education, 40, 375-407.

Meyer, J. H. F. (1995). Gender differences in the learning behaviour of entering first-year university students. Higher Education, 29, 20-215.

Mouw, J. T., \& Khanna, R. K. (1993). Prediction of academic success: A review of the literature and some recommendations. College Student Journal, 27, 328-336.

Nelson, B., Dunn, R., Griggs, S. A., Primavera, L., Fitzpatrick, M., Bacilious, Z., \& Miller, R. (1993). Effects of learning style intervention on college students' retention and achievement. Journal of College Student Development, 34, 364-369.

Pintrich, P. R., \& DeGroot, E. (1990). Motivational and self-regulated learning components of classroom academic performance. Journal of Educational Psychology, 82, 33-40.

Pokay, P., \& Blumenfeld, P. C. (1990). Predicting achievement early and late in the semester: The role of motivation and use of learning strategies. Journal of Educational Psychology, 82, 41-50.

Polansky, J., Horan, J. J., \& Hanish, C. (1993). Experimental construct validity of the outcomes of 
study skills training and career counseling as treatment for the retention of at-risk students. Journal of Counseling and Development, 71, 488-492.

Robbins, S. B., Lauver, K., Le, H., Davis, D., Langley, R., \& Carlstrom, A. (2004). Do psychosocial and study skill factors predict college outcomes? Psychological Bulletin, 130, 261-288.

Schultz, P. A., \& Lanehart, S. L. (1994). Long-term educational goals, subgoals, learning strategies use and the academic performance of college students. Learning and Individual Differences, 6, 399-412.

Severiens, S. E., \& Ten Dam, G. T. (1994). Gender differences in learning styles: A narrative review and quantitative meta-analysis. Higher Education, 27, 487-501.

Soares, A. P., Almeida, L. S., Diniz, A., \& Guisande, M. A. (2006). Modelo Multidimensional de Ajustamento de jovens ao contexto Universitário (MMAU): Validação com alunos de ciências e tecnologias versus alunos de ciências sociais e humanas Análise Psicológica, 1, 15-28.

Soares, A. P., Guisande, M. A., Diniz, A., \& Almeida, L. S. (2006). Construcción y validación de un modelo multidimensional de ajuste de los jóvenes al contexto universitario. Psicothema, 18, 249-255.

Tavares, J., Almeida, L. S., Vasconcelos, R., \& Bessa, J. (2003). Inventário de Atitudes e Comportamentos Habituais de Estudo. Braga, Portugal: Universidade do Minho.

Trigwell, K., \& Prosser, M. (1991). Improving the quality of student learning: The influence of learning context and student approaches to learning on learning outcomes. Higher Education, 22, 251-266.

Young, J. W., \& Fisler, J. L. (2000). Sex differences on the SAT: An analysis of demografic and educational variables. Research in Higher Education, 41, 401-416.

Zhang, L. F. (2000). University students' learning approaches in three cultures: An investigation of Bigg's 3P model. The Journal of Psychology, 134, 37-55.

Zheng, J. L., Kevin, L., Saunders, P., \& Shelley, M. C. (2002). Predictors of academic success for freshmen residence hall students. Journal of College Student Development, 43, 267-273. 